(RESEARCH ARTICLE)

\title{
Recent performance appraisal of six Nigerian seaports using multivariate and data envelopment analysis
}

\author{
Kenneth Ezebunwa Ndubuisi ${ }^{1}$ and Chinyeaka Nwokodi Nwoloziri 2,* \\ ${ }^{1}$ Department of Maritime Management Technology, School of Management Technology, Federal University of Technology \\ Owerri, Nigeria. \\ 2Department of Maritime Management Technology, School of Management Technology, Federal University of Technology \\ Owerri, Nigeria.
}

Publication history: Received on 01 November 2020; revised on 22 November 2020; accepted on 04 December 2020

Article DOI: https://doi.org/10.30574/wjaets.2020.1.2.0026

\begin{abstract}
Performance appraisal is a regular check which every organization adapts to regulate the performance of its establishment. It shows the relationships between outputs and input variables in organizations. The objective of the study is to review the performance of six Nigerian seaports between the periods of 2012-2017 by applying Data Envelopment Analysis (DEA), General Linear Model (GLM), and Multivariate Analysis (MVA) models. Data collected from Nigerian Ports Authority (NPA) statistics covers the periods (2012-2017) for each port. The empirical result shows that the following Seaports performed efficiently: Lagos Port (LP) in 2014, Tin Can Island Port (TCP) in 2014, Onne Port (OP) in 2014, and Calabar Port (CP) in 2012, 2013, 2014 and 2016. The least efficient performed seaport is Delta Port (DP) in 2012. Hence, the most efficient port over the years under study is Calabar Port (CP) while least performed port is Delta Port (DP). The results of the regression model and the multivariate analysis reject the null hypothesis and accept that at $5 \%$ level of significance there is a significant relationship between the input variables and output variables of each port, even that $\mathrm{P}$-value is less than $0.005(\mathrm{P}<0.05)$.
\end{abstract}

Keywords: $\quad$ Performance Appraisal; Ports; Data Envelopment Analysis (DEA); General Linear Model (GLM); Multivariate Analysis (MVA); Nigerian Seaports.

\section{Introduction}

Performance appraisal is a fundamental concept to every business organization because all businesses are interested to know their strength and productivity rate which could help to guide against rivals in the business environment, while also measuring her achievements in terms of relationships between output/input variables towards achieving set goals and objectives. Seaports are complex business environment with huge investments as inputs resources with expected results as outputs resources which could be proven through return on investment (ROI) for purposes of sustainable development. To evaluate returns on investment in seaports, operators have employed many techniques of ports performance measurement. However, the recommendations on evaluation of seaports performances have compelled stakeholders and policy makers to take some reform decisions such as privatization and concession of seaports basically to increase productivity or efficiency. This has led to academic interest in seaport performance measures. Hence, this paper will appraise the performance of six Nigerian seaports from 2012 to 2017 using Data Envelopment Analysis (DEA) while applying Multivariate Analysis to evaluate the effect of input variables on the output variables as well as the relationship between inputs and output variables. The results of this research will aid the policy makers, investors and port operators on different ways to invest in seaport operations for greater efficiency.

\footnotetext{
${ }^{*}$ Corresponding author: Chinyeaka Nwokodi Nwoloziri

Department of Maritime Management Technology, School of Management Technology, Federal University of Technology Owerri, Nigeria.
}

Copyright (@ 2020 Author(s) retain the copyright of this article. This article is published under the terms of the Creative Commons Attribution Liscense 4.0. 


\subsection{Background Information}

Maritime transportation as a major channel of international trade has been subjected to deliberate efforts to improving the efficiency of the sector. The maritime industry is a vital and strategic sector in every country's economy. According to UNCTAD [27], international sea borne trade, from 1980 to 2008 witnessed an increase of over 120\%. According to Umang [26], this increase was possible due to the steady growth in world population, rapid industrialization, and the depletion of local resources, road congestion, increase in the need for better living standard and elimination of trade barriers. He also claimed that since the beginning of the decade, dry bulk, liquid bulk and containerized cargo have registered an impressive tonnage increase of 52\%, 48\% and 154\% respectively. In this period of high globalized production and consumption driven by increase in world population with limited available resources, there is a growing need for efficient and productive supply chain management which cannot be without the high efficiency of seaports that serves as the interface between maritime and hinterland transport systems. The fluidity of movement of goods and services within a region aids increase in socio-economic development of such region. This is made possible based on the performance of the seaports. According to Emeghara and Ndikom [9] they reiterated that ship and port relationship is like that of a master/servant relationship. A port is likened to be an enterprise established to provide quality service to her masters/customers to survive economically. This is because shippers as well as ship owners demand efficient service from port operators for continual patronage. Nigeria is endowed with marine domain with estuaries hosting harbors, ports and jetties. However, it is vital to note that the deliberate distribution of vessel traffic in accordance to final consumer's location reduces acute traffic congestions in some ports. Considerably, the importance of ports in the economic life of any nation cannot be over emphasized. According to Managing Director NPA Hadiza Bala Usman in her opening remarks in NPA as reported in [16], she posits that the critical role of ports in national economic and social development is derived from its significance as the cheapest mode of moving large cargoes from one point to another. The demand for port services by vessels is, however, a derived demand earned through conscious and deliberate policy choices made and driven to create the enabling environment for ship operators to make a first call to our ports and make a repeat call thereafter. While the government reforms leading to the concession of cargo operations to private terminal operators (PTOs) represented the foundation for improving efficiency through huge infrastructural investment for smooth and fast service delivery, the ongoing commitment to improve the competitiveness of Nigerian ports and the renewed commitment to pull the country out of the most challenging recession experienced in over two decades represents a key government priority. But the lack of convincing, tangible and concerted effort of the Nigerian government to mitigate the congestion at Lagos Ports and also the incessant sea robbery and militancy challenges in the Nigeria waterways have affected businesses in the Nigerian ports as perceived by port stakeholders which is contrary to the government assertion [19].

\subsection{Overview of Nigerian Seaports}

The explorations and trade activities of Europeans in Nigeria created the demand for seaports on the wide coastal stretch between Calabar and Lagos. In the $15^{\text {th }}$ century European voyagers discovered the rich natural resources of West and Central Africa - resources they needed for their economic and industrial revolution and this gave birth to Nigerian seaports as we have them today.

In 1906, dredgers were commissioned to work at the Lagos bar and the approval to construct the first section of the East Mole was obtained. This is the first major breakthrough in opening up the Lagos Lagoon. In 1913 the development of Apapa Port was hatched and in 1921 the construction of the first four deepwater berths at Apapa, with a length of 1,800 ft, began. In 1948 an additional 2,500 ft of berths were installed with a reclaimed area of 41ha to accommodate transit sheds, warehouses and marshalling yards. The discovery of coal in Enugu led to the building of the Rivers Port (Port Harcourt wharf) in the first quarter of the century and in 1913 Port Harcourt Port was opened to shipping by the Governor General, Lord Luggard. A berth for colliers was created so that coal could be loaded from rail to ship. Four berths of $1,920 \mathrm{ft}$ were further developed at Port Harcourt Ports in 1927. Prior to 1954, Port operations and management were controlled by Railway Corporation Department in charge of cargo handling, Public Works Department in charge of quay maintenance and Marine Department responsible for maintenance of the harbours, channels, and berthing of vessels.

In 1954, the Nigerian Ports Authority was established by an Act of Parliament (Port Act, CAP155 Laws of the Federation of Nigeria and Lagos 1955, currently NPA Act CAP N126 LFN, 2004) to control and maintain the seaports as well as load and discharge cargo. Its operations started on 1 April 1955. In 1982, Nigerian maritime industry began to feel the impact of the economic recession in spite of government policies to boost product export as against an earlier booming importation business that had kept Nigeria seaports congested and busy since the early 1970s. The decline in government revenue led to public private partnership (PPP) arrangement in port development through port concession. On 17 June 1992 the Authority was incorporated as a public liability company under the provision of the Companies and Allied Matters Act 1990 as a wholly owned government company. However, in 1999 the status of the Nigerian Ports 
Authority was reverted to as an Agency of the Federal Republic of Nigeria supervised by the Ministry of Transport. Presently, Nigeria has six seaports namely Lagos Port, Tin Can Island Port, Rivers Port, Onne Port, Calabar Port and Delta Ports. They are along the coastline region of the country covering a stretch of over $853 \mathrm{~km}$, between $4^{\circ} 10^{\prime}$ and $6^{\circ} 20^{\prime}$ north and between $2^{\circ} 45^{\prime}$ and $8^{\circ} 35^{\prime}$ east.

\subsubsection{The Lagos Port Complex}

The Lagos Port Complex is the oldest and largest port in Nigeria termed Premiere Port also referred to as Apapa Quays. It is situated in Lagos State, the commercial capital of Nigeria. The port is concession to the following companies: papa Bulk Terminal Limited Apapa Terminal A and B; Green-view Dev. Nig. Ltd. Apapa Terminal E; and APM Terminals Limited Apapa Container Terminal for 25 years respectively; while ENL Consortium Apapa Terminal C, ENL Consortium Apapa Terminal D and Lily pond Container Depot Nigeria Ltd Ijora Container Depot for10 years respectively.

\subsubsection{Tin Can Island Port}

Tin Can Island Port is located within the north-west of Lagos Port Complex built in the mid 1970s in response to an increase in economic activities during the oil boom coupled with post-civil-war reconstruction, rehabilitation and reintegration efforts by the then military government. The port is concession to the following companies: Joseph dam Ports Services Limited TCIP Terminal A, and Ports \& Cargo Handling Services Ltd. TCIP Terminal C for 10 years respectively; Tin Can Island Container Limited TCIP Terminal B and Five Star Logistics Limited TCIP RORO Terminal for 15 years respectively; and Port \& Terminal Multi services Limited TCIP Terminal E for 25 years.

\subsubsection{Rivers Port Complex}

Rivers Port Complex, Port Harcourt is the second-oldest port in Nigeria but is the first port to be established in the east of Niger in the country after the Lagos Port Complex, Apapa. The port is concession to Ports \& Terminal Operators Nig. Ltd. Port Harcourt Terminal A for 15years; and BUA Ports \& Terminals Limited Port Harcourt Terminal B for 25 years

\subsubsection{Onne Port Complex}

Onne Port Complex is situated on the Bonny River Estuary along Ogu Creek. As a flagship port it is the first of its kind in Nigeria that operates the Landlord Port Model devised to encourage private sector participation in the Port Industry. It is one of the largest Oil and Gas Free Zones in the world supporting exploration and production for Nigerian activities. The Free Zone provides logistics Oil Service centre for the Oil and Gas Industry in Nigeria both Onshore and Offshore operations. The port is strategically located as it provides easy access to the entire West African and Sub-Sahara Oil Onne Port Complex fields. The seaport accounts for over $65 \%$ of the export cargo through the Nigerian Seaport. The port is concession to Intels Nigeria Limited Onne FOT A, Brawal Oil Services Ltd. Onne FLT A, Intels Nigeria Ltd. Onne FLT B and Atlas Cement Co. Limited Jetty FOT Onne for 25 years respectively.

\subsubsection{Calabar Port}

Calabar Port is made up of facilities built and operated previously by various shipping companies which used to serve as an important trading port in the pre-colonial era. The port has supervisory responsibility over crude oil terminals at Antan, Odudu, Yoho and Qua Iboe. Passenger boat services covering Cameroon, Gabon and other West and Central African countries operate from here. The port is concession to Intels Nigeria Limited Calabar New Terminal A, Addax Logistics Nigeria Limited Calabar Terminal C (Old Port) for 25 years respectively and Ecomarine Nig. Limited Calabar New Terminal B for 10 years.

\subsubsection{Delta Port}

Delta Port is home to the ports of Warri, Sapele, Koko and Burutu at the heart of the Niger Delta. Warri Port is the coordinating point for management and administration of other ports in the delta, operating from natural harbors. By virtue of their geographical location, these ports have land in sufficient quantity for investment purposes more than all the others. The port is concession to Intels Nigeria Limited Warri Old Port Terminal A and B for 25 years respectively, Julius Berger Plc Warri New Port Terminal C for 25 years and Associated Maritime Services Limited Warri Old Port Terminal B and Greenling Limited Koko Terminal for 10years respectively. 
Table 1 The summary of the Characteristics of the six Nigerian Seaports

\begin{tabular}{|c|c|c|c|c|c|c|c|c|c|c|c|c|c|c|}
\hline$S / N$ & $\begin{array}{l}\text { Name of } \\
\text { jetty }\end{array}$ & Year & $\begin{array}{l}\text { Quay } \\
\text { length }\end{array}$ & $\begin{array}{l}\text { No. of } \\
\text { berths }\end{array}$ & $\begin{array}{l}\text { Total } \\
\text { port area }\end{array}$ & $\begin{array}{l}\text { Access } \\
\text { channel } \\
\text { draft }\end{array}$ & $\begin{array}{l}\text { Cargo } \\
\text { throughput }\end{array}$ & $\begin{array}{l}\text { Ship } \\
\text { traffic }\end{array}$ & $\begin{array}{l}\text { GRT } \\
\text { Ocean } \\
\text { going }\end{array}$ & $\begin{array}{l}\text { Service } \\
\text { boat }\end{array}$ & $\begin{array}{l}\text { GRT } \\
\text { service } \\
\text { boat }\end{array}$ & $\begin{array}{l}\text { ATT } \\
\text { (days) }\end{array}$ & BOR\% & $\begin{array}{l}\text { Vehicle } \\
\text { traffic }\end{array}$ \\
\hline \multirow[t]{6}{*}{1} & \multirow{6}{*}{$\begin{array}{l}\text { LAGOS } \\
\text { PORT } \\
\text { complex }\end{array}$} & 2012 & 2537 & 21 & 200ha & 14 & 19951807 & 1445 & 3207798 & 191 & 380444 & 5.13 & 55.76 & 17121 \\
\hline & & 2013 & 2537 & 21 & 200ha & 14 & 20437369 & 1510 & 34189172 & NA & NA & 5.13 & 55.76 & 14397 \\
\hline & & 2014 & 2537 & 21 & 200ha & 14 & 20645269 & 1503 & 37046879 & NA & NA & 5.13 & 55.76 & 9611 \\
\hline & & 2015 & 2537 & 21 & 200ha & 14 & 20250771 & 1410 & 36290502 & NA & NA & 5.13 & 55.76 & 6955 \\
\hline & & 2016 & 2537 & 21 & $200 \mathrm{ha}$ & 14 & 19055385 & 1194 & 33612421 & NA & NA & 5.13 & 55.76 & 346 \\
\hline & & 2017 & 2537 & 21 & 200ha & 14 & 19099690 & 1154 & 31932784 & 1 & 2876 & 5.13 & 55.76 & 507 \\
\hline \multirow[t]{6}{*}{2} & \multirow{6}{*}{$\begin{array}{l}\text { TinCan port } \\
\text { complex }\end{array}$} & 2012 & 3396 & 13 & 158 & 14 & 15268897 & 1508 & 32636886 & NA & NA & 4.01 & 43.92 & 251322 \\
\hline & & 2013 & 3396 & 13 & 158 & 14 & 16134153 & 1615 & 40096754 & NA & NA & 4.01 & 43.92 & 265209 \\
\hline & & 2014 & 3396 & 13 & 158 & 14 & 17500804 & 1692 & 47231548 & NA & NA & 4.01 & 43.92 & 237904 \\
\hline & & 2015 & 3396 & 13 & 158 & 14 & 16407133 & 1656 & 45864565 & NA & NA & 4.01 & 43.92 & 124841 \\
\hline & & 2016 & 3396 & 13 & 158 & 14 & 15648919 & 1559 & 45229402 & NA & NA & 4.01 & 43.92 & 104571 \\
\hline & & 2017 & 3396 & 13 & 158 & 14 & 15464385 & 1350 & 41477915 & NA & NA & 4.01 & 43.92 & 180758 \\
\hline \multirow[t]{6}{*}{3} & \multirow{6}{*}{$\begin{array}{l}\text { Rivers port } \\
\text { Complex }\end{array}$} & 2012 & 704 & 8 & 58 & 10 & 5574653 & 499 & 7210520 & NA & NA & 6.85 & 37.67 & NA \\
\hline & & 2013 & 704 & 8 & 58 & 10 & 4935944 & 439 & 6207092 & NA & NA & 6.85 & 37.67 & NA \\
\hline & & 2014 & 704 & 8 & 58 & 10 & 6225008 & 435 & 6632480 & NA & NA & 6.85 & 37.67 & NA \\
\hline & & 2015 & 704 & 8 & 58 & 10 & 4457785 & 373 & 5423002 & NA & NA & 6.85 & 37.67 & NA \\
\hline & & 2016 & 704 & 8 & 58 & 10 & 3574235 & 319 & 4951913 & NA & NA & 6.85 & 37.67 & NA \\
\hline & & 2017 & 704 & 8 & 58 & 10 & 3536873 & 309 & 5277722 & NA & NA & 6.85 & 37.67 & 141 \\
\hline \multirow[t]{2}{*}{4} & \multirow{2}{*}{$\begin{array}{l}\text { OnnePort } \\
\text { Complex }\end{array}$} & 2012 & 5172 & FLT4/FOT12 & 2638199 & 11 & 27580642 & 859 & 42910262 & 3637 & 5494535 & 21.4 & 11.46 & 285 \\
\hline & & 2013 & & FLT4/F0T12 & 2638199 & 11 & & & & & & 21.4 & 11.46 & \\
\hline
\end{tabular}


World Journal of Advanced Engineering Technology and Sciences, 2020, 01(02), 001-020

\begin{tabular}{|c|c|c|c|c|c|c|c|c|c|c|c|c|c|c|}
\hline & & 2013 & 5172 & FLT4/F0T12 & 2638199 & 11 & 24773387 & 823 & 38612995 & 3534 & 47 & 21.4 & 11.46 & 260 \\
\hline & & 2014 & 5172 & FLT4/F0T12 & 2638199 & 11 & 27968861 & 847 & 45543000 & 3455 & 5678989 & 21.4 & 11.46 & 106 \\
\hline & & 2015 & 5172 & FLT4/F0T12 & 2638199 & 11 & 26314828 & 741 & 44053589 & 1305 & 2326922 & 21.4 & 11.46 & 196 \\
\hline & & 2016 & 5172 & FLT4/F0T12 & 2638199 & 11 & 23434241 & 659 & 40091365 & 1823 & 3582303 & 21.4 & 11.46 & 272 \\
\hline & & 2017 & 5172 & FLT4/F0T12 & 2638199 & 11 & 26049226 & 671 & 42818946 & 1916 & 3671556 & 21.4 & 11.46 & 3 \\
\hline \multirow[t]{6}{*}{5} & \multirow{6}{*}{$\begin{array}{l}\text { Calabar } \\
\text { Port }\end{array}$} & 2012 & NP86/0P88 & 7 & 88 & 6 & 6987533 & 615 & 2767531 & 508 & 333801 & 5.18 & 22.93 & NA \\
\hline & & 2013 & NP86/0P88 & 7 & 88 & 6 & 10361746 & 609 & 2834884 & 198 & 99669 & 5.18 & 22.93 & NA \\
\hline & & 2014 & NP86/0P88 & 7 & 88 & 6 & 10199169 & 603 & 4008361 & 35 & 31147 & 5.18 & 22.93 & NA \\
\hline & & 2015 & NP86/0P88 & 7 & 88 & 6 & 7829862 & 528 & 3796652 & 35 & 31147 & 5.18 & 22.93 & NA \\
\hline & & 2016 & NP86/0P88 & 7 & 88 & 6 & 6836616 & 438 & 4207733 & 53 & 28522 & 5.18 & 22.93 & NA \\
\hline & & 2017 & NP86/0P88 & 7 & 88 & 6 & 5197773 & 448 & 3880058 & 55 & 13090 & 5.18 & 22.93 & NA \\
\hline \multirow[t]{6}{*}{6} & \multirow{6}{*}{$\begin{array}{l}\text { Delta Port } \\
\text { Complex }\end{array}$} & 2012 & 572 & NB7/OB18 & 353 & 6 & 1723195 & 159 & 3220686 & 17390 & 2480436 & 3.48 & 13 & 658 \\
\hline & & 2013 & 572 & NB7/OB19 & 353 & 6 & 1732286 & 373 & 8667160 & 15602 & 2510700 & 3.48 & 13 & 360 \\
\hline & & 2014 & 572 & NB7/OB20 & 353 & 6 & 2361477 & 269 & 7860797 & 10755 & 2038242 & 3.48 & 13 & 311 \\
\hline & & 2015 & 572 & NB7/OB21 & 353 & 6 & 2127259 & 306 & 5822393 & 7276 & 909390 & 3.48 & 13 & 2 \\
\hline & & 2016 & 572 & NB7/OB22 & 353 & 6 & 2329984 & 453 & 6120242 & 7542 & 1582577 & 3.48 & 13 & NA \\
\hline & & 2017 & 572 & NB7/OB23 & 353 & 6 & 2187689 & 403 & 6182396 & 9787 & 1771834 & 3.48 & 13 & NA \\
\hline
\end{tabular}




\section{Literature review}

The globalization of the world economy has tremendously increased the importance of the maritime transportation role vis-à-vis seaports internationally. This has lent great credence to all nodes or echelons of the economic global supply chain. However, the seaports as an important node in the supply chain process of international trade have been under the searchlight of investors, governments and academia over the years and especially in the recent time of technological era. This is as a result of its performance importance in the survival of most countries of the world, hence the huge technological input or investment in the sector. Therefore, for the sake of such huge investment in the maritime sector world over, these seaports are subjected to competition which in turn leads to the monitoring of their productivity and efficiency. Studies on port efficiency, productivity or performance are done regularly within the port organization or externally by academic researchers in many parts of the world. A number of such studies have done by many researchers. Considerably, Hlali ([11] who estimated and compared the technical efficiency of the container ports using both data envelopment analysis (DEA) and stochastic frontier analysis (SFA) models to check the role of the characteristics of infrastructure on container port efficiency based on cross-sectional data for 26 world's major container ports in 2015.

Evangelos, [7] in their paper, measured US Ports efficiency by analyzing port productivity using Data Envelopment Analysis technique on containerization and traditional port operations. They obtained two main results. First, a set of the best practice ports was identified. Second, the sources and extent of inefficiency on which an inefficient port should focus in order to improve their operations were determined.

Evangelos [8] also evaluated the efficiency of major North American container ports and terminals using Data Envelopment Analysis (DEA) and the Free Disposal Hull (FDH) Model. However, the results show that the above two techniques lead to different conclusions. Furthermore, they concluded that the availability of panel data, rather than cross sectional data, would improve the validity of the efficiency estimates derived from all applied mathematical programming techniques. Tongzon [23] study applied data envelopment analysis (DEA) to provide an efficiency measurement for four Australian and twelve other international container ports. The ports of Melbourne, Rotterdam, Yokohama and Osaka are found to be the most inefficient ports in the sample, based on constant and variable returns to scale assumptions, mainly due to the enormous slack in their container berths, terminal area and labor inputs. The study also drew some policy implications for ports and recommends certain areas for future research.

DEA application in port efficiency is growing over the years, Turner, [24] applied Data Envelopment Analysis (DEA) technique in the productivity study of North America ports using a panel data from 1984 - 1997. Jara-Diaz, [13] researched on 26 Spanish seaports, estimating a multi output cost function using a flexible form from a sample of over an 11-year period. Talley [22] also compared the actual performance of seaport with optimum throughput over a specific time period. Karen, [14] analyzed the efficiency of available elements used at public port terminals located in the state of Espírito Santo, Brazil. In Northeast Asia, SoonHoo, [21] applied DEA models, to measure the operational efficiency of the 19 major container ports in the Northeast Asia. This analysis of operational efficiency revealed the causes of inefficient operation and also suggests how to overcome the drawbacks. An additional analysis for ranking the container ports was conducted using the super-efficiency model. According to the results of this study, eight container ports are operated efficiently among which Hongkong is ranked top as the most efficient port in the Northeast Asia. Two Korean container ports, both Busan and Gwangyang show relatively low operational efficiency compared to their rival ports and suggested to either cut labour and capital (inputs) or increase TEU (output) of the two ports to improve efficiency.

Hong-Oanh, [12] applied bootstrapped DEA to a sample of 43 largest Vietnamese ports and compared the results with those from stochastic frontier analysis (SFA) and standard DEA. The results showed that while the efficiency scores obtained from the three methods provide useful and consistent measures of the ports' efficiency, they differed significantly. Furthermore, while the efficiency scores produced by bootstrapped DEA are consistent, unbiased, and not sensitive to the sample size, standard DEA and SFA yielded efficiency scores that were much larger than bootstrapped DEA. In addition, bootstrapped DEA provided the confidence intervals for efficiency scores and allowed for hypothesis tests of port performance.

Medal-Bartual, [15] assessed the impact of the economic crisis on the productivity growth of the Spanish Port System (SPS). The Malmquist Productivity Index (MPI) was estimated for the 28 Port Authorities of the SPS, for a 'non-crisis period' (2005-2008) and a 'crisis period' (2008-2011). From a policy perspective, the MPI is a very useful approach for assessing the productivity change because it can be decomposed into the catching-up index and the frontier productivity index. The results showed that the economic crisis did not impact all of the Spanish Port Authorities equally. Some Port Authorities presented higher productivity growth during the crisis period than in the non-crisis period. Further analysis 
by the Mann-Whitney test revealed that Port Authority investments and productivity growth were statistically related. The findings illustrate that the economic crisis should not be seen as an international tragedy, but as an opportunity to adapt port traffics and installations to new needs and market demands.

However, in a developing country like Nigeria, Peter [19] focused on assessing the efficiency of six major Nigerian ports from 2007 to 2013 by applying a two-stage fuzzy-based methodology adequate to handle imprecise data. More precisely, fuzzy data envelopment analysis models for traditional assumptions with respect to scale returns were employed to assess the productivity of Nigerian ports over the course of time. In the second stage, fuzzy regressions based on different rule-based systems were used to predict the relationship of a set of contextual variables on port efficiency. These contextual variables are related to different aspects of port service level, berth utilization, accessibility, cargo type, and operator type. The results revealed the impact of operator and cargo type on efficiency levels. Policy implications for Nigerian ports are derived. Nwanosike, [10] applied a Malmquist Productivity Index (MPI) technique to benchmark pre-and post-reform total factor productivity growth of the six major Nigeria seaports namely Tin Can Island, Apapa, Calabar, Onne, Port Harcourt, and Warri for the periods (2000-2011) which represents six years before (2000-2005) and six years after (2006-2011) the reform. The results indicated progress in technical efficiency of the ports after reform but deterioration in technological progress. Overall productivity growth was higher in the preconcession period compared to the post-concession period. Okeudo, [18] focused on the impact of reforms on port performance using Onne and Rivers ports in Nigeria as a reference point and she applied DEA to analyze the pre and post reform eras of the ports in terms of their performance for the period 2001 to 2010. Madueke, [25] applied DEA and OEE in analyzing the performance of Atlas Cove liquid bulk terminal and depot facility in Nigeria by benchmarking efficiency and productivity levels of the facility. Onwuegbuchunam, [17] applied Stochastic Frontier Analysis model in assessing the productivity and efficiency of Nigeria's seaports, the study revealed that total factor productivity of the port averages greater than 2.5 million tons per annum. In addition, capital input is statistically significant while labour input is insignificant in the port productivity. However, he suggested that DEA should be applied to incorporate multiple output variables. He also suggested the development of a hybrid model that can incorporate the advantages of SFA and DEA in seaport efficiency analysis.

A. S. Ogunsiji \& 0. O. Ogunsiji [1] explored the problems bedeviling the various efficiency measurement techniques of ports performance. They identified the Matching Framework Analysis (MFA) as the appropriate method for measuring performance and efficiency at the Nigeria ports, cognizant of disproportionate problems attendant to the simple operations there. The application of MFA, matched the identifiable problems to the three major configurations of environment, structure and strategy over a period six years (2001-2006) therefore making ground breaking recommendations that could plummet the driving capability of the port for economic growth and development.

The above references and more shows that DEA has been applied internationally but there is a gap on the Nigerian ports efficiency studies. There is a lack of assessment on Nigerian ports from multiple inputs and super multiple outputs standpoint which exists in the port complexes. This is the interest of the researcher. This study adopts Data Envelopment Analysis Model for this purpose, covering a period from 2012 to 2017. For further studies the application of different models in analyzing port efficiency for developing countries like Nigeria should be encouraged.

\section{Methodology}

In this study both deterministic and behavioral approaches were adopted. The approaches authenticate the data from the studied seaports as published by Nigerian Ports Authority. The data used for the study were secondary data gotten from the websites of Nigerian Ports Authority (NPA), NPA Bulletin and Handbook. Some of the data were reconfirmed by direct observation and random questions to cargo surveyors and vessel pilots. The secondary data comprises the following input variables; Quay Length, Number of Berth, Total Port Area, and Access Channel Draft, while the output variables used were Ship Traffic, Cargo Throughput, and GRT Ocean going. These data were collected for a seven-year period from 2012 to 2017.

\subsubsection{Model specification}

For the analysis of data the following statistical models were applied to assess and answer the research questions namely; Data Envelopment Analysis Model, Generalized Linear Model, and Multivariate Analysis Techniques.

\subsubsection{Data Envelopment Analysis (DEA)}

Data Envelopment Analysis is a non-parametric model for measuring the efficiency of Decision Making Units (DMU) with multiple inputs and or multiple outputs. Charnes, [4] first introduced the DEA as a multi-factor productivity analysis module for measuring the relative efficiencies of DMUs. The DEA analysis shows how inputs and output have 
to be changed in order to maximize the efficiency levels of the target DMU. DEA is used in this study because of its suitability in analyzing efficiency of transit services such as seaports.

DEA as developed by Charnes, [4] explain that suppose we have a set of $\mathrm{n}$ peers DMUs which produces multiple output vector Y by using observed multiple input vector X respectively.

Where,

$\mathrm{X}=$ input vector used in the DMUs.

Y= output vector produced by DMUs.

$€$ is a constant non Archimedean (infinitesimal of the order of 10-6) that insures no input or output is given a zero weight $s+$ and $s-$ is the slack vectors for output and input respectively

$\theta=$ represents the proportional reduction of the input in relation to the amount of the projected input. The optimal value of $\lambda$ forms a composite unit outperforming the DMU under analysis and providing targets for this DMU to identify sources of its inefficiency. This model is known as input-oriented BCC, the initial being in recognition of its formulators and users $[2,3,5$, and 6$]$

Then the production possibility set will be defined as follows in relation to this study:

Thus:

$\mathrm{F}=\{(\mathrm{Y}, \mathrm{X}) / \mathrm{X}$ can produce $\mathrm{Y}\}$

As cited by [20]

Where in this study n=Lagos Port Complex(LPC), Tin Can Island Port(TCP), Rivers Port Complex(RPC),Onne Port Complex(OPC),Calabar Port(CP), Delta Port complex(DPC)

Y= Quay Length (QL), Number of Berth (Berths), Total Port Area (TPA), and Access Channel Draft (ACD)

X= Ship Traffic (ST), Cargo Throughput (CTP), GRT Ocean Going (GOG),

According to Cooper [5], the performance of a DMU is efficient if and only if it is not possible to improve any input or output without worsening any other input or output, while the performance of a DMU is inefficient if and only if it is possible to improve some input or output without worsening some other input and output. (Pareto-Koopmans Definition of Efficiency)

Hence, DEA model is a linear programming model applied on the input-output variables to empirically or quantitatively estimate the technical and scale efficiency of all the 6 Nigerian seaports for a 6 years period, using 36 industrial-years as the decision making units (DMUs). These will determine the level of inefficiency plus the input/output slack that would have been needed to make them efficient. The efficiency scores were computed using an Open Access R-Statistical Software version 3.4 designed by The R Foundation for Statistical Computing (2018). The analysis were done both under constant return to scale (CRS) and variable return to scale (VRS) so as to determine first the Technical Efficiency (TE) as well as the extent to which scale of operation affected port performance (i.e. scale efficiency). Efficiency of DMUs range between 0 and 1, and any unit that has a score of unity (1) is considered efficient, while those DMUs with less than 1 (unity) are considered inefficient.

Further focus was on how to highlight associated input/output slack among the DMUs or various industrial-years. This will enable managements to determine necessary adjustment for input/output mix to achieve efficient performance.

\subsubsection{Generalized Linear Model}

The generalized linear model (GLM) is a flexible generalization of ordinary linear regression that allows for response variables that have error distribution models other than a normal distribution. The GLM generalizes linear regression by allowing the linear model to be related to the response variable via a link function and by allowing the magnitude of the variance of each measurement to be a function of its predicted value. Generalized linear models were formulated 
by John Nelder and Robert Wedderburn as a way of unifying various other statistical models, including linear regression, logistic regression and Poisson regression. They proposed an iteratively reweighted least squares method for maximum likelihood estimation of the model parameters. Maximum-likelihood estimation remains popular and is the default method on many statistical computing packages. Other approaches, including Bayesian approaches and least squares fits to variance stabilized responses, have been developed.

The Generalized Linear model is a family of linear model that is applied when the dependent variable of a regression model is not normally distributed. It uses appropriate link functions depending on the nature of the dependent variable. Here we will adopt normal regression model (Linear regression model), Gamma Regression Model and Inverse Gaussian regression model with identity link.

A general linear model is given by:

$$
\phi(i)=\beta_{0}+\beta_{1} X_{1}+\beta_{2} X_{2}+\ldots+\beta_{n} X_{n}+\varepsilon_{i}
$$

Where,

$\begin{array}{ll}\phi(i) \quad-\quad & \text { is the link function of the dependent variable, here the output variables. } \\ X_{i}^{s} \quad-\quad & \text { th }^{\text {th }} \text { independent variables (here the input variables) } \\ \beta_{i}^{s} & -\quad \text { regression coefficients } \\ \varepsilon_{i} & \quad-\quad \text { error component. }\end{array}$

\subsubsection{Multivariate Analysis Techniques}

Multivariate analysis (MVA) techniques allow more than two variables to be analyzed at once. Two general types of MVA technique are Analysis of dependence and Analysis of interdependence. Many statistical techniques focus on just one or two variables. Multivariate analysis (MVA) techniques allow more than two variables to be analyzed at once. The ultimate goal of these analyses is either explanation or prediction, i.e., more than just establishing an association.

The four common test statistics for multivariate test are given thus:

Pillai $(\mathrm{V})=\sum_{i=1}^{s} \frac{\lambda_{i}}{1+\lambda_{i}}$

LawLey-Hotellings $(\mathrm{U})=\sum_{i=1}^{s} \lambda_{i}$

Wilks's Lambda $\Lambda=\prod_{i=1}^{s} \frac{1}{1+\lambda_{i}}$

Roy's Largest Root $\theta=\frac{\lambda_{1}}{1+\lambda_{1}}$

Where, $\lambda$ is the Eigen values from the product of covariance matrices of the sum of squares of error and due to fit of the model. 


\subsection{Data presentation and interpretation}

Table 2Input and Output Data Used For the Study of 6 Nigerian Ports

\begin{tabular}{|c|c|c|c|c|c|c|c|c|c|}
\hline SN & JETTIES & YEAR & $\mathbf{Q L}$ & BERTHS & TPA & ACD & CTP & ST & GOG \\
\hline \multirow[t]{6}{*}{1} & LP & 2012 & 2537 & 21 & 200 & 13.5 & 19951807 & 1445 & 32072798 \\
\hline & & 2013 & 2537 & 21 & 200 & 13.5 & 20437369 & 1510 & 34189172 \\
\hline & & 2014 & 2537 & 21 & 200 & 13.5 & 20645269 & 1503 & 37046879 \\
\hline & & 2015 & 2537 & 21 & 200 & 13.5 & 20250771 & 1410 & 36290502 \\
\hline & & 2016 & 2537 & 21 & 200 & 13.5 & 19055385 & 1194 & 33612421 \\
\hline & & 2017 & 2537 & 21 & 200 & 13.5 & 19099690 & 1154 & 31932784 \\
\hline \multirow[t]{6}{*}{2} & TCP & 2012 & 3396 & 13 & 157.808 & 14 & 15268897 & 1508 & 32636886 \\
\hline & & 2013 & 3396 & 13 & 157.808 & 14 & 16134153 & 1615 & 40096754 \\
\hline & & 2014 & 3396 & 13 & 157.808 & 14 & 17500804 & 1692 & 47231548 \\
\hline & & 2015 & 3396 & 13 & 157.808 & 14 & 16407133 & 1656 & 45864565 \\
\hline & & 2016 & 3396 & 13 & 157.808 & 14 & 15648919 & 1559 & 45229402 \\
\hline & & 2017 & 3396 & 13 & 157.808 & 14 & 15464385 & 1350 & 41477915 \\
\hline \multirow[t]{6}{*}{3} & $\mathrm{RP}$ & 2012 & 704 & 8 & 58 & 9.5 & 5574653 & 499 & 7210520 \\
\hline & & 2013 & 704 & 8 & 58 & 9.5 & 4935944 & 439 & 6207092 \\
\hline & & 2014 & 704 & 8 & 58 & 9.5 & 6225008 & 435 & 6632480 \\
\hline & & 2015 & 704 & 8 & 58 & 9.5 & 4457785 & 373 & 5423002 \\
\hline & & 2016 & 704 & 8 & 58 & 9.5 & 3574235 & 319 & 4951913 \\
\hline & & 2017 & 704 & 8 & 58 & 9.5 & 3536873 & 309 & 5277722 \\
\hline \multirow[t]{6}{*}{4} & $\mathrm{OP}$ & 2012 & 5172 & 16 & 2638.199 & 11 & 27580642 & 859 & 42910262 \\
\hline & & 2013 & 5172 & 16 & 2638.199 & 11 & 24773387 & 823 & 38612995 \\
\hline & & 2014 & 5172 & 16 & 2638.199 & 11 & 27968861 & 847 & 45543000 \\
\hline & & 2015 & 5172 & 16 & 2638.199 & 11 & 26314828 & 741 & 44053589 \\
\hline & & 2016 & 5172 & 16 & 2638.199 & 11 & 23434241 & 659 & 40091365 \\
\hline & & 2017 & 5172 & 16 & 2638.199 & 11 & 26049226 & 671 & 42818946 \\
\hline \multirow[t]{6}{*}{5} & $\mathrm{CP}$ & 2012 & 174 & 7 & 88 & 6.4 & 6987533 & 615 & 2767531 \\
\hline & & 2013 & 174 & 7 & 88 & 6.4 & 10361746 & 609 & 2834884 \\
\hline & & 2014 & 174 & 7 & 88 & 6.4 & 10199169 & 603 & 4008361 \\
\hline & & 2015 & 174 & 7 & 88 & 6.4 & 7829862 & 528 & 3796652 \\
\hline & & 2016 & 174 & 7 & 88 & 6.4 & 6836616 & 438 & 4207733 \\
\hline & & 2017 & 174 & 7 & 88 & 6.4 & 5197773 & 448 & 3880058 \\
\hline \multirow[t]{6}{*}{6} & $\mathrm{DP}$ & 2012 & 572 & 25 & 352.67 & 5.9 & 1723195 & 159 & 3220686 \\
\hline & & 2013 & 572 & 25 & 352.67 & 5.9 & 1732286 & 373 & 8667160 \\
\hline & & 2014 & 572 & 25 & 352.67 & 5.9 & 2361477 & 269 & 7860797 \\
\hline & & 2015 & 572 & 25 & 352.67 & 5.9 & 2127259 & 306 & 5822393 \\
\hline & & 2016 & 572 & 25 & 352.67 & 5.9 & 2329984 & 453 & 6120242 \\
\hline & & 2017 & 572 & 25 & 352.67 & 5.9 & 2187689 & 403 & 6182396 \\
\hline
\end{tabular}




\section{Results}

Table 3 Input and output Slack for DEA under Variable Return to Scale Model

\begin{tabular}{|c|c|c|c|c|c|c|c|c|c|c|c|c|c|c|}
\hline \multirow{2}{*}{ DMU Name } & \multirow{2}{*}{ TEvrs } & \multirow{2}{*}{ RTS } & \multicolumn{4}{|c|}{ Actual Input Variables } & \multicolumn{4}{|c|}{ Input Target } & \multicolumn{4}{|c|}{ Input Slack } \\
\hline & & & QL & Berths & TPA & ACD & QL & Berths & TPA & ACD & QL & Berths & TPA & ACD \\
\hline LP2012 & 0.96 & IRS & 2537 & 21 & 200 & 14 & 2436 & 20 & 192 & 13 & 101 & 1 & 8 & 1 \\
\hline LP2013 & 0.99 & IRS & 2537 & 21 & 200 & 14 & 2512 & 21 & 198 & 14 & 25 & 0 & 2 & 0 \\
\hline LP2014 & 1.00 & CRS & 2537 & 21 & 200 & 14 & 2537 & 21 & 200 & 14 & 0 & 0 & 0 & 0 \\
\hline LP2015 & 0.98 & DRS & 2537 & 21 & 200 & 14 & 2486 & 21 & 196 & 14 & 51 & 0 & 4 & 0 \\
\hline LP2016 & 0.92 & DRS & 2537 & 21 & 200 & 14 & 2334 & 19 & 184 & 13 & 203 & 2 & 16 & 1 \\
\hline LP2017 & 0.91 & IRS & 2537 & 21 & 200 & 14 & 2309 & 19 & 182 & 13 & 228 & 2 & 18 & 1 \\
\hline ТСР2012 & 0.89 & DRS & 3396 & 13 & 158 & 14 & 3022 & 12 & 141 & 12 & 374 & 1 & 17 & 2 \\
\hline ТCР2013 & 0.95 & DRS & 3396 & 13 & 158 & 14 & 3226 & 12 & 150 & 13 & 170 & 1 & 8 & 1 \\
\hline ТСР2014 & 1.00 & CRS & 3396 & 13 & 158 & 14 & 3396 & 13 & 158 & 14 & 0 & 0 & 0 & 0 \\
\hline ТСР2015 & 0.98 & DRS & 3396 & 13 & 158 & 14 & 3328 & 13 & 155 & 14 & 68 & 0 & 3 & 0 \\
\hline ТСР2016 & 0.96 & DRS & 3396 & 13 & 158 & 14 & 3260 & 12 & 152 & 13 & 136 & 1 & 6 & 1 \\
\hline ТСР2017 & 0.88 & DRS & 3396 & 13 & 158 & 14 & 2988 & 11 & 139 & 12 & 408 & 2 & 19 & 2 \\
\hline RP2012 & 0.96 & DRS & 704 & 8 & 58 & 10 & 676 & 8 & 56 & 10 & 28 & 0 & 2 & 0 \\
\hline RP2013 & 0.85 & DRS & 704 & 8 & 58 & 10 & 598 & 7 & 49 & 9 & 106 & 1 & 9 & 2 \\
\hline RP2014 & 0.93 & DRS & 704 & 8 & 58 & 10 & 655 & 7 & 54 & 9 & 49 & 1 & 4 & 1 \\
\hline RP2015 & 0.72 & DRS & 704 & 8 & 58 & 10 & 507 & 6 & 42 & 7 & 197 & 2 & 16 & 3 \\
\hline RP2016 & 0.62 & DRS & 704 & 8 & 58 & 10 & 436 & 5 & 36 & 6 & 268 & 3 & 22 & 4 \\
\hline RP2017 & 0.60 & DRS & 704 & 8 & 58 & 10 & 422 & 5 & 35 & 6 & 282 & 3 & 23 & 4 \\
\hline OP2012 & 0.99 & DRS & 5172 & 16 & 2638199 & 11 & 5120 & 16 & 2611817 & 11 & 52 & 0 & 26382 & 0 \\
\hline OP2013 & 0.93 & DRS & 5172 & 16 & 2638199 & 11 & 4810 & 15 & 2453525 & 10 & 362 & 1 & 184674 & 1 \\
\hline OP2014 & 1.00 & CRS & 5172 & 16 & 2638199 & 11 & 5172 & 16 & 2638199 & 11 & 0 & 0 & 0 & 0 \\
\hline OP2015 & 0.97 & DRS & 5172 & 16 & 2638199 & 11 & 5017 & 16 & 2559053 & 11 & 155 & 0 & 79146 & 0 \\
\hline OP2016 & 0.88 & DRS & 5172 & 16 & 2638199 & 11 & 4551 & 14 & 2321615 & 10 & 621 & 2 & 316584 & 1 \\
\hline OP2017 & 0.94 & DRS & 5172 & 16 & 2638199 & 11 & 4862 & 15 & 2479907 & 10 & 310 & 1 & 158292 & 1 \\
\hline CP2012 & 1.00 & CRS & 174 & 7 & 88 & 6 & 174 & 7 & 88 & 6 & 0 & 0 & 0 & 0 \\
\hline CP2013 & 1.00 & CRS & 174 & 7 & 88 & 6 & 174 & 7 & 88 & 6 & 0 & 0 & 0 & 0 \\
\hline CP2014 & 1.00 & CRS & 174 & 7 & 88 & 6 & 174 & 7 & 88 & 6 & 0 & 0 & 0 & 0 \\
\hline СР2015 & 0.94 & DRS & 174 & 7 & 88 & 6 & 164 & 7 & 83 & 6 & 10 & 0 & 5 & 0 \\
\hline СР2016 & 1.00 & CRS & 174 & 7 & 88 & 6 & 174 & 7 & 88 & 6 & 0 & 0 & 0 & 0 \\
\hline СР2017 & 0.93 & DRS & 174 & 7 & 88 & 6 & 162 & 7 & 82 & 6 & 12 & 0 & 6 & 0 \\
\hline DP2012 & 0.35 & DRS & 572 & 25 & 353 & 6 & 200 & 9 & 124 & 2 & 372 & 16 & 229 & 4 \\
\hline DP2013 & 0.93 & DRS & 572 & 26 & 353 & 6 & 532 & 24 & 328 & 6 & 40 & 2 & 25 & 0 \\
\hline DP2014 & 0.85 & DRS & 572 & 27 & 353 & 6 & 486 & 23 & 300 & 5 & 86 & 4 & 53 & 1 \\
\hline DP2015 & 0.63 & DRS & 572 & 28 & 353 & 6 & 360 & 18 & 222 & 4 & 212 & 10 & 131 & 2 \\
\hline DP2016 & 0.703 & DRS & 572 & 29 & 353 & 6 & 402 & 20 & 248 & 4 & 170 & 9 & 105 & 2 \\
\hline DP2017 & 0.67 & DRS & 572 & 30 & 353 & 6 & 383 & 20 & 237 & 4 & 189 & 10 & 116 & 2 \\
\hline
\end{tabular}


Table 3 cont Input and Output Slack for DEA under Constant Return to Scale Model

\begin{tabular}{|c|c|c|c|c|c|c|c|c|c|c|c|}
\hline \multirow{2}{*}{ DMU Name } & \multirow{2}{*}{ TEvrs } & \multicolumn{3}{|c|}{ Actual Output Variables } & \multicolumn{3}{|c|}{ Output Target } & \multicolumn{3}{|c|}{ Output Slack } & \multirow{2}{*}{ Benchmark } \\
\hline & & СTP & ST & GOG & СТP & ST & GOG & СTP & ST & GOG & \\
\hline LP2012 & 0.96 & 19951807 & 1445 & 32072798 & 19153735 & 1387 & 30789886 & 798072 & 58 & 1282912 & LP2014 \\
\hline LP2013 & 0.99 & 20437369 & 1510 & 34189172 & 20232995 & 1495 & 33847280 & 204374 & 15 & 341892 & LP2014 \\
\hline LP2014 & 1.00 & 20645269 & 1503 & 37046879 & 20645269 & 1503 & 37046879 & 0 & 0 & 0 & LP2014 \\
\hline LP2015 & 0.98 & 20250771 & 1410 & 36290502 & 19845756 & 1382 & 35564692 & 405015 & 28 & 725810 & LP2014 \\
\hline LP2016 & 0.92 & 19055385 & 1194 & 33612421 & 17530954 & 1098 & 30923427 & 1524431 & 96 & 2688994 & LP2014 \\
\hline LP2017 & 0.91 & 19099690 & 1154 & 31932784 & 17380718 & 1050 & 29058833 & 1718972 & 104 & 2873951 & LP2014 \\
\hline ТСР2012 & 0.89 & 15268897 & 1508 & 32636886 & 13589318 & 1342 & 29046829 & 1679579 & 166 & 3590057 & ТСР2014 \\
\hline ТСР2013 & 0.95 & 16134153 & 1615 & 40096754 & 15327445 & 1534 & 38091916 & 806708 & 81 & 2004838 & ТСР2014 \\
\hline ТСР2014 & 1.00 & 17500804 & 1692 & 47231548 & 17500804 & 1692 & 47231548 & 0 & 0 & 0 & ТСР2014 \\
\hline ТCР2015 & 0.98 & 16407133 & 1656 & 45864565 & 16078990 & 1623 & 44947274 & 328143 & 33 & 917291 & ТCР2014 \\
\hline ТCР2016 & 0.96 & 15648919 & 1559 & 45229402 & 15022962 & 1497 & 43420226 & 625957 & 62 & 1809176 & ТСР2014 \\
\hline ТСР2017 & 0.88 & 15464385 & 1350 & 41477915 & 13608659 & 1188 & 36500565 & 1855726 & 162 & 4977350 & ТСР2014 \\
\hline RP2012 & 0.96 & 5574653 & 499 & 7210520 & 5351667 & 479 & 6922099 & 222986 & 20 & 288421 & ТСР2014 \\
\hline RP2013 & 0.85 & 4935944 & 439 & 6207092 & 4195552 & 373 & 5276028 & 740392 & 66 & 931064 & ТСР2014 \\
\hline RP2014 & 0.93 & 6225008 & 435 & 6632480 & 5789257 & 405 & 6168206 & 435751 & 30 & 464274 & ТСР2014 \\
\hline RP2015 & 0.72 & 4457785 & 373 & 5423002 & 3209605 & 269 & 3904561 & 1248180 & 104 & 1518441 & ТСР2014 \\
\hline RP2016 & 0.62 & 3574235 & 319 & 4951913 & 2216026 & 198 & 3070186 & 1358209 & 121 & 1881727 & ТСР2014 \\
\hline RP2017 & 0.60 & 3536873 & 309 & 5277722 & 2122124 & 185 & 3166633 & 1414749 & 124 & 2111089 & ТСР2014 \\
\hline OP2012 & 0.99 & 27580642 & 859 & 42910262 & 27304836 & 850 & 42481159 & 275806 & 9 & 429103 & OP2014 \\
\hline OP2013 & 0.93 & 24773387 & 823 & 38612995 & 23039250 & 765 & 35910085 & 1734137 & 58 & 2702910 & OP2014 \\
\hline OP2014 & 1.00 & 27968861 & 847 & 45543000 & 27968861 & 847 & 45543000 & 0 & 0 & 0 & OP2014 \\
\hline OP2015 & 0.97 & 26314828 & 741 & 44053589 & 25525383 & 719 & 42731981 & 789445 & 22 & 1321608 & OP2014 \\
\hline OP2016 & 0.88 & 23434241 & 659 & 40091365 & 20622132 & 580 & 35280401 & 2812109 & 79 & 4810964 & OP2014 \\
\hline OP2017 & 0.94 & 26049226 & 671 & 42818946 & 24486272 & 631 & 40249809 & 1562954 & 40 & 2569137 & OP2014 \\
\hline СР2012 & 1.00 & 6987533 & 615 & 2767531 & 6987533 & 615 & 2767531 & 0 & 0 & 0 & СР2012 \\
\hline СР2013 & 1.00 & 10361746 & 609 & 2834884 & 10361746 & 609 & 2834884 & 0 & 0 & 0 & СР2013 \\
\hline СР2014 & 1.00 & 10199169 & 603 & 4008361 & 10199169 & 603 & 4008361 & 0 & 0 & 0 & СР2014 \\
\hline СР2015 & 0.94 & 7829862 & 528 & 3796652 & 7360070 & 496 & 3568853 & 469792 & 32 & 227799 & CP2012 \\
\hline СР2016 & 1.00 & 6836616 & 438 & 4207733 & 6836616 & 438 & 4207733 & 0 & 0 & 0 & CP2016 \\
\hline CР2017 & 0.93 & 5197773 & 448 & 3880058 & 4833929 & 417 & 3608454 & 363844 & 31 & 271604 & СР2012 \\
\hline DP2012 & 0.35 & 1723195 & 159 & 3220686 & 603118 & 56 & 1127240 & 1120077 & 103 & 2093446 & CP2012 \\
\hline DP2013 & 0.93 & 1732286 & 373 & 8667160 & 1611026 & 347 & 8060459 & 121260 & 26 & 606701 & CР2012 \\
\hline DP2014 & 0.85 & 2361477 & 269 & 7860797 & 2007255 & 229 & 6681677 & 354222 & 40 & 1179120 & СР2012 \\
\hline DP2015 & 0.63 & 2127259 & 306 & 5822393 & 1340173 & 193 & 3668108 & 787086 & 113 & 2154285 & СР2012 \\
\hline DP2016 & 0.70 & 2329984 & 453 & 6120242 & 1637979 & 318 & 4302530 & 692005 & 135 & 1817712 & СР2012 \\
\hline DP2017 & 0.67 & 2187689 & 403 & 6182396 & 1465752 & 270 & 4142205 & 721937 & 133 & 2040191 & CP2012 \\
\hline
\end{tabular}

Source: Results on efficiency using Open Access R-statistical Software Version 3.4 
Table 4 Input and Output Slack for DEA under Variable Return to Scale Model

\begin{tabular}{|c|c|c|c|c|c|c|c|c|c|c|c|c|c|c|}
\hline \multirow{2}{*}{ DMU Name } & \multirow{2}{*}{ TEvrs } & \multirow{2}{*}{ RTS } & \multicolumn{4}{|c|}{ Actual Input Variables } & \multicolumn{4}{|c|}{ Input Target } & \multicolumn{4}{|c|}{ Input Slack } \\
\hline & & & $Q L$ & Berths & $T P A$ & $A C D$ & $Q L$ & Berths & $T P A$ & $A C D$ & $Q L$ & Berths & $T P A$ & $A C D$ \\
\hline LP2012 & 0.96 & IRS & 2537 & 21 & 200 & 14 & 2436 & 20 & 192 & 13 & 101 & 1 & 8 & 1 \\
\hline LP2013 & 1.00 & CRS & 2537 & 21 & 200 & 14 & 2537 & 21 & 200 & 14 & 0 & 0 & 0 & 0 \\
\hline LP2014 & 1.00 & CRS & 2537 & 21 & 200 & 14 & 2537 & 21 & 200 & 14 & 0 & 0 & 0 & 0 \\
\hline LP2015 & 0.98 & DRS & 2537 & 21 & 200 & 14 & 2486 & 21 & 196 & 14 & 51 & 0 & 4 & 0 \\
\hline LP2016 & 0.93 & DRS & 2537 & 21 & 200 & 14 & 2359 & 20 & 186 & 13 & 178 & 1 & 14 & 1 \\
\hline LP2017 & 0.92 & IRS & 2537 & 21 & 200 & 14 & 2334 & 19 & 184 & 13 & 203 & 2 & 16 & 1 \\
\hline ТСР2012 & 0.92 & DRS & 3396 & 13 & 158 & 14 & 3124 & 12 & 145 & 13 & 272 & 1 & 13 & 1 \\
\hline ТСР2013 & 0.97 & DRS & 3396 & 13 & 158 & 14 & 3294 & 13 & 153 & 14 & 102 & 0 & 5 & 0 \\
\hline ТСР2014 & 1.00 & CRS & 3396 & 13 & 158 & 14 & 3396 & 13 & 158 & 14 & 0 & 0 & 0 & 0 \\
\hline ТСР2015 & 0.99 & DRS & 3396 & 13 & 158 & 14 & 3362 & 13 & 156 & 14 & 34 & 0 & 2 & 0 \\
\hline ТСР2016 & 0.98 & DRS & 3396 & 13 & 158 & 14 & 3328 & 13 & 155 & 14 & 68 & 0 & 3 & 0 \\
\hline ТСР2017 & 1.00 & CRS & 3396 & 13 & 158 & 14 & 3396 & 13 & 158 & 14 & 0 & 0 & 0 & 0 \\
\hline RP2012 & 1.00 & CRS & 704 & 8 & 58 & 10 & 704 & 8 & 58 & 10 & 0 & 0 & 0 & 0 \\
\hline RP2013 & 1.00 & CRS & 704 & 8 & 58 & 10 & 704 & 8 & 58 & 10 & 0 & 0 & 0 & 0 \\
\hline RP2014 & 1.00 & CRS & 704 & 8 & 58 & 10 & 704 & 8 & 58 & 10 & 0 & 0 & 0 & 0 \\
\hline RP2015 & 1.00 & CRS & 704 & 8 & 58 & 10 & 704 & 8 & 58 & 10 & 0 & 0 & 0 & 0 \\
\hline RP2016 & 1.00 & CRS & 704 & 8 & 58 & 10 & 704 & 8 & 58 & 10 & 0 & 0 & 0 & 0 \\
\hline RP2017 & 0.99 & DRS & 704 & 8 & 58 & 10 & 697 & 8 & 57 & 10 & 7 & 0 & 1 & 0 \\
\hline OP2012 & 0.93 & DRS & 5172 & 16 & 2638199 & 11 & 4810 & 15 & 2453525 & 10 & 362 & 1 & 184674 & 1 \\
\hline OP2013 & 1.00 & CRS & 5172 & 16 & 2638199 & 11 & 5172 & 16 & 2638199 & 11 & 0 & 0 & 0 & 0 \\
\hline OP2014 & 0.98 & CRS & 5172 & 16 & 2638199 & 11 & 5069 & 16 & 2585435 & 11 & 103 & 0 & 52764 & 0 \\
\hline OP2015 & 0.94 & DRS & 5172 & 16 & 2638199 & 11 & 4862 & 15 & 2479907 & 10 & 310 & 1 & 158292 & 1 \\
\hline OP2016 & 0.97 & DRS & 5172 & 16 & 2638199 & 11 & 5017 & 16 & 2559053 & 11 & 155 & 0 & 79146 & 0 \\
\hline OP2017 & 1.00 & CRS & 5172 & 16 & 2638199 & 11 & 5172 & 16 & 2638199 & 11 & 0 & 0 & 0 & 0 \\
\hline СР2012 & 1.00 & CRS & 174 & 7 & 88 & 6 & 174 & 7 & 88 & 6 & 0 & 0 & 0 & 0 \\
\hline СР2013 & 1.00 & CRS & 174 & 7 & 88 & 6 & 174 & 7 & 88 & 6 & 0 & 0 & 0 & 0 \\
\hline CP2014 & 1.00 & CRS & 174 & 7 & 88 & 6 & 174 & 7 & 88 & 6 & 0 & 0 & 0 & 0 \\
\hline CP2015 & 1.00 & CRS & 174 & 7 & 88 & 6 & 174 & 7 & 88 & 6 & 0 & 0 & 0 & 0 \\
\hline CР2016 & 1.00 & CRS & 174 & 7 & 88 & 6 & 174 & 7 & 88 & 6 & 0 & 0 & 0 & 0 \\
\hline CP2017 & 1.00 & CRS & 174 & 7 & 88 & 6 & 174 & 7 & 88 & 6 & 0 & 0 & 0 & 0 \\
\hline DP2012 & 1.00 & CRS & 572 & 25 & 353 & 6 & 572 & 25 & 353 & 6 & 0 & 0 & 0 & 0 \\
\hline DP2013 & 1.00 & CRS & 572 & 26 & 353 & 6 & 572 & 26 & 353 & 6 & 0 & 0 & 0 & 0 \\
\hline DP2014 & 1.00 & CRS & 572 & 27 & 353 & 6 & 572 & 27 & 353 & 6 & 0 & 0 & 0 & 0 \\
\hline DP2015 & 1.00 & CRS & 572 & 28 & 353 & 6 & 572 & 28 & 353 & 6 & 0 & 0 & 0 & 0 \\
\hline DP2016 & 1.00 & CRS & 572 & 29 & 353 & 6 & 572 & 29 & 353 & 6 & 0 & 0 & 0 & 0 \\
\hline DP2017 & 1.00 & CRS & 572 & 30 & 353 & 6 & 572 & 30 & 353 & 6 & 0 & 0 & 0 & 0 \\
\hline
\end{tabular}


Table 4 cont Input and Output Slack for DEA under Variable Return to Scale Model

\begin{tabular}{|c|c|c|c|c|c|c|c|c|c|c|c|}
\hline \multirow{2}{*}{ DMU Name } & \multirow{2}{*}{ TEvrs } & \multicolumn{3}{|c|}{ Actual Output Variables } & \multicolumn{3}{|c|}{ Output Target } & \multicolumn{3}{|c|}{ Output Slack } & \multirow{2}{*}{ Benchmark } \\
\hline & & СТP & ST & GOG & СTP & ST & GOG & СТP & ST & GOG & \\
\hline LP2012 & 0.96 & 19951807 & 1445 & 32072798 & 19153735 & 1387 & 30789886 & 798072 & 58 & 1282912 & LP2013 \\
\hline LP2013 & 1.00 & 20437369 & 1510 & 34189172 & 20437369 & 1510 & 34189172 & 0 & 0 & 0 & LP2013 \\
\hline LP2014 & 1.00 & 20645269 & 1503 & 37046879 & 20645269 & 1503 & 37046879 & 0 & 0 & 0 & LP2014 \\
\hline LP2015 & 0.98 & 20250771 & 1410 & 36290502 & 19845756 & 1382 & 35564692 & 405015 & 28 & 725810 & LP2013 \\
\hline LP2016 & 0.93 & 19055385 & 1194 & 33612421 & 17721508 & 1110 & 31259552 & 1333877 & 84 & 2352869 & LP2013 \\
\hline LP2017 & 0.92 & 19099690 & 1154 & 31932784 & 17571715 & 1062 & 29378161 & 1527975 & 92 & 2554623 & LP2013 \\
\hline ТСР2012 & 0.92 & 15268897 & 1508 & 32636886 & 14047385 & 1387 & 30025935 & 1221512 & 121 & 2610951 & ТСР2014 \\
\hline ТСР2013 & 0.97 & 16134153 & 1615 & 40096754 & 15650128 & 1567 & 38893851 & 484025 & 48 & 1202903 & ТСР2014 \\
\hline ТСР2014 & 1.00 & 17500804 & 1692 & 47231548 & 17500804 & 1692 & 47231548 & 0 & 0 & 0 & ТСР2014 \\
\hline ТCР2015 & 0.99 & 16407133 & 1656 & 45864565 & 16243062 & 1639 & 45405919 & 164071 & 17 & 458646 & ТCР2014 \\
\hline ТCР2016 & 0.98 & 15648919 & 1559 & 45229402 & 15335941 & 1528 & 44324814 & 312978 & 31 & 904588 & ТCР2014 \\
\hline ТСР2017 & 1.00 & 15464385 & 1350 & 41477915 & 15464385 & 1350 & 41477915 & 0 & 0 & 0 & ТСР2014 \\
\hline RP2012 & 1.00 & 5574653 & 499 & 7210520 & 5574653 & 499 & 7210520 & 0 & 0 & 0 & ТСР2017 \\
\hline RP2013 & 1.00 & 4935944 & 439 & 6207092 & 4935944 & 439 & 6207092 & 0 & 0 & 0 & ТСР2012 \\
\hline RP2014 & 1.00 & 6225008 & 435 & 6632480 & 6225008 & 435 & 6632480 & 0 & 0 & 0 & ТСР2013 \\
\hline RP2015 & 1.00 & 4457785 & 373 & 5423002 & 4457785 & 373 & 5423002 & 0 & 0 & 0 & ТСР2014 \\
\hline RP2016 & 1.00 & 3574235 & 319 & 4951913 & 3574235 & 319 & 4951913 & 0 & 0 & 0 & ТСР2016 \\
\hline RP2017 & 0.99 & 3536873 & 309 & 5277722 & 3501504 & 306 & 5224945 & 35369 & 3 & 52777 & ТСР2012 \\
\hline OP2012 & 0.93 & 27580642 & 859 & 42910262 & 25649997 & 799 & 39906544 & 1930645 & 60 & 3003718 & OP2014 \\
\hline OP2013 & 1.00 & 24773387 & 823 & 38612995 & 24773387 & 823 & 38612995 & 0 & 0 & 0 & OP2014 \\
\hline OP2014 & 0.98 & 27968861 & 847 & 45543000 & 27409484 & 830 & 44632140 & 559377 & 17 & 910860 & OP2014 \\
\hline OP2015 & 0.94 & 26314828 & 741 & 44053589 & 24735938 & 697 & 41410374 & 1578890 & 44 & 2643215 & OP2014 \\
\hline OP2016 & 0.97 & 23434241 & 659 & 40091365 & 22731214 & 639 & 38888624 & 703027 & 20 & 1202741 & OP2014 \\
\hline OP2017 & 1.00 & 26049226 & 671 & 42818946 & 26049226 & 671 & 42818946 & 0 & 0 & 0 & OP2014 \\
\hline СР2012 & 1.00 & 6987533 & 615 & 2767531 & 6987533 & 615 & 2767531 & 0 & 0 & 0 & СРС2012 \\
\hline СР2013 & 1.00 & 10361746 & 609 & 2834884 & 10361746 & 609 & 2834884 & 0 & 0 & 0 & СРC2013 \\
\hline СР2014 & 1.00 & 10199169 & 603 & 4008361 & 10199169 & 603 & 4008361 & 0 & 0 & 0 & СРС2014 \\
\hline СР2015 & 1.00 & 7829862 & 528 & 3796652 & 7829862 & 528 & 3796652 & 0 & 0 & 0 & СРС2012 \\
\hline СР2016 & 1.00 & 6836616 & 438 & 4207733 & 6836616 & 438 & 4207733 & 0 & 0 & 0 & СРС2016 \\
\hline CР2017 & 1.00 & 5197773 & 448 & 3880058 & 5197773 & 448 & 3880058 & 0 & 0 & 0 & СРС2012 \\
\hline DP2012 & 1.00 & 1723195 & 159 & 3220686 & 1723195 & 159 & 3220686 & 0 & 0 & 0 & СРС2012 \\
\hline DP2013 & 1.00 & 1732286 & 373 & 8667160 & 1732286 & 373 & 8667160 & 0 & 0 & 0 & СРС2012 \\
\hline DP2014 & 1.00 & 2361477 & 269 & 7860797 & 2361477 & 269 & 7860797 & 0 & 0 & 0 & СРС2012 \\
\hline DP2015 & 1.00 & 2127259 & 306 & 5822393 & 2127259 & 306 & 5822393 & 0 & 0 & 0 & СРС2012 \\
\hline DP2016 & 1.00 & 2329984 & 453 & 6120242 & 2329984 & 453 & 6120242 & 0 & 0 & 0 & СРC2012 \\
\hline DP2017 & 1.00 & 2187689 & 403 & 6182396 & 2187689 & 403 & 6182396 & 0 & 0 & 0 & СРС2012 \\
\hline
\end{tabular}


Table 5 Generalized Linear Model of the Cargo Throughput (CTP) on Input Variables

\begin{tabular}{|l|l|l|l|}
\hline \multirow{2}{*}{$\begin{array}{l}\text { Model } \\
\text { Coefficient }\end{array}$} & \multicolumn{3}{|l|}{ Families of Generalized Linear Model } \\
\cline { 2 - 4 } Constant & Normal & Gamma & Inverse Gaussian \\
\hline \multirow{3}{*}{ QL } & -1476596.050 & 14901819.910 & 17034296.836 \\
& $(0.678)$ & $(0.000)$ & $(0.000)$ \\
\hline \multirow{3}{*}{ Berths } & 2281.982 & 9778.846 & 11075.353 \\
& $(0.085)$ & $(0.000)$ & $(0.000)$ \\
\hline \multirow{3}{*}{ TPA } & -39058.687 & -368306.103 & -390745.074 \\
& $(0.634)$ & $(0.000)$ & $(0.000)$ \\
\hline \multirow{2}{*}{ ACD } & 2.500 & -7.330 & -9.060 \\
& $(0.159)$ & $(0.030)$ & $(0.046)$ \\
\hline
\end{tabular}

Source: Analytical result from the application of SPSS Version 20

Table 6 Generalized Linear Model of the Ship Traffic (ST) on Input Variables

\begin{tabular}{|l|l|l|l|}
\hline \multirow{2}{*}{$\begin{array}{l}\text { Model } \\
\text { Coefficient }\end{array}$} & \multicolumn{3}{|l|}{ Families of Generalized Linear Model } \\
\cline { 2 - 4 } Constant & $\begin{array}{l}\text { Normal } \\
\text { G28.349 } \\
(0.013)\end{array}$ & $\begin{array}{l}1096.260 \\
(0.000)\end{array}$ & $\begin{array}{l}\text { Inverse Gaussian } \\
(0.000)\end{array}$ \\
\hline \multirow{3}{*}{ QL } & 0.437 & 0.729 & 0.814 \\
& $(0.000)$ & $0.000)$ & $(0.000)$ \\
\hline \multirow{3}{*}{ Berths } & -6.901 & -19.493 & -21.787 \\
& $(0.083)$ & $(0.000)$ & $(0.000)$ \\
\hline \multirow{3}{*}{ TPA } & -0.001 & -0.001 & -0.001 \\
& $(0.000)$ & $(0.000)$ & $(0.000)$ \\
\hline \multirow{2}{*}{ ACD } & -12.942 & -101.520 & -123.232 \\
& $(0.564)$ & $0.000)$ & $(0.000)$ \\
\hline
\end{tabular}

Table 7Generalized Linear Model of the GRT Ocean Going (GOG) on Input Variables

\begin{tabular}{|c|c|c|c|}
\hline \multirow{2}{*}{$\begin{array}{l}\text { Model } \\
\text { Coefficient }\end{array}$} & \multicolumn{3}{|c|}{ Families of Generalized Linear Model } \\
\hline & Normal & Gamma & Inverse Gaussian \\
\hline Constant & $\begin{array}{l}-230516.531 \\
(0.943)\end{array}$ & $\begin{array}{l}11948686.515 \\
(0.000)\end{array}$ & \multirow{5}{*}{ Could not Fit the Data } \\
\hline QL & $\begin{array}{l}13194.771 \\
(0.000)\end{array}$ & $\begin{array}{l}18119.141 \\
(0.000)\end{array}$ & \\
\hline Berths & $\begin{array}{l}29412.871 \\
(0.693)\end{array}$ & $\begin{array}{l}-205224.740 \\
(0.000)\end{array}$ & \\
\hline TPA & $\begin{array}{l}-9.378 \\
(0.000)\end{array}$ & $\begin{array}{l}-15.702 \\
(0.000)\end{array}$ & \\
\hline ACD & $\begin{array}{l}-127617.884 \\
(0.761)\end{array}$ & $\begin{array}{l}-1692182.290 \\
(0.000)\end{array}$ & \\
\hline
\end{tabular}


Table 8 Multivariate Analysis of the Effect of Input Variables on output Variables

\begin{tabular}{|l|l|l|l|l|l|l|}
\hline $\begin{array}{l}\text { Model } \\
\text { Coefficient }\end{array}$ & $\begin{array}{l}\text { Pillai's } \\
\text { Trace }\end{array}$ & $\begin{array}{l}\text { Wilks' } \\
\text { Lambda }\end{array}$ & $\begin{array}{l}\text { Hotelling's } \\
\text { Trace }\end{array}$ & $\begin{array}{l}\text { Roy's } \\
\text { Largest } \\
\text { Root }\end{array}$ & F & p-value \\
\hline Constant & 0.46 & 0.54 & 0.851 & 0.851 & 8.22 & 0.000 \\
\hline QL & 0.862 & 0.138 & 6.269 & 6.269 & 60.60 & 0.000 \\
\hline Berths & 0.195 & 0.805 & 0.242 & 0.242 & 2.34 & 0.094 \\
\hline TPA & 0.894 & 0.106 & 8.392 & 8.392 & 81.11 & 0.000 \\
\hline ACD & 0.389 & 0.611 & 0.638 & 0.638 & 6.16 & 0.002 \\
\hline
\end{tabular}

\section{Discussion}

Table3 is the DEA results of the ports under study when Constant Return to Scale is considered. The result is on the year, technical efficiency of each port, the return to scale status, the input target, output target, input slack and output slack. The efficiency value 1 shows that the port performed very efficiently with best input mix. The further the value of efficiency is from 1 , the poorer the performance of that port in that particular year.

The result in table3 shows that the least efficient year/port was Delta Port (DP) in 2012 with efficiency value 0.35. On the average, Calabar Port (CP) was the most efficient port within the years under review.

For the Return to Scales, we have three classes:

Constant Return to Scale (CRS) which are those with efficiency 1 and input variables equals input targets, i.e. zero slack variables.

Increase Return to Scale (IRS) which deals with port that requires some changes in input mix. Here decrease is required on the input variables for the output to be optimum. This return to scale depicts excess or waste of input resources.

Decrease Return to Scale (DRS), this is the direct opposite of IRS. More input variables are needed to achieve optimum output.

On the slack variables, the slack values greater than zero signifies the input variables either to be added/remove depending return to scale.

Table3 is equivalent of the Table4 except that it is on Variable Return to Scale. Every other information remains the same but with consideration to variable return to scale.

However, a test for fitness of both indicated that the constant return to scale is more appropriate for the study data. We recommend that inference be based on that.

Table5i is on the generalized linear model of an output variable Cargo Throughput (CTP) on the input variables. This linear model enabled the researcher to evaluate the effect of each input variables on CTP. The families of the Generalized Linear model adopted because of the nature of the study data are Normal (Linear Regression model), Gamma regression model and Inverse Gaussian regression model. The result showed that the Gamma and Inverse regression model best fitted the data set with each coefficient significant $(\mathrm{p}<0.05)$. The coefficients are interpreted thus using Gamma regression model:

The value of the coefficient of Quay Length (QL) equals 9778.846 which imply an increase in QL will lead to increase in Cargo Throughput (CTP) by about 9779 when other input variables are held constant.

The value of the coefficient of Berths equals -368306.103 which implies an increase in the number of Berths by one will lead to a decrease in Cargo Throughput (CTP) by about 368306 when other input variables remain unchanged. 
The value of the coefficient of Total Port Area (TPA) equals -7.330, indicates that when every other input variables in the model are held constant, that an increase in TPA by one unit will lead to a decrease in Cargo Throughput (CTP) by about 7 .

The value of the coefficient of Access Channel Depth (ACD) equals -1293427.9 indicate that when every other input variables in the model are held constant, an increase in ACD by one unit will lead to a decrease in Cargo Throughput (CTP) by about 1293428 .

Table5ii is on the generalized linear model of an output variable Ship Traffic (ST) on the input variables. This linear model enabled the researcher to evaluate the effect of each input variables on Ship Traffic (ST). The families of the Generalized Linear model adopted because of the nature of the study data are Normal (Linear Regression model), Gamma Regression Model and Inverse Gaussian Regression Model. The result showed that the Gamma and Inverse regression model best fitted the data set with each coefficient significant $(\mathrm{p}<0.05)$. The coefficients are interpreted thus using Gamma regression model:

The value of the coefficient of Quay Length (QL) equals 0.729 which implies that an increase in QL will lead to increase in Ship Traffic (ST) by about .729 when other input variables are held constant.

The value of the coefficient of Berths equals -19.493 which implies an increase in the number of Berths by one will lead to a decrease in Ship Traffic (ST) by about 19.493 when other input variables remain unchanged.

The value of the coefficient of Total Port Area (TPA) equals -0.001, which indicates that when every other input variable in the model are held constant that an increase in TPA by one unit will lead to a decrease in Ship Traffic (ST) by about 0.001 .

The value of the coefficient of Access Channel Depth (ACD) equals -101.520 which indicates that when every other input variables in the model are held constant, an increase in ACD by one unit will lead to a decrease in Ship Traffic (ST) by about 101.520 .

Table5iii is on the generalized linear model of an output variable Gross Registered Tonnage Ocean Going (GOG) on the input variables. This linear model enabled the researcher to evaluate the effect of each input variables on Gross Registered Tonnage Ocean Going (GOG). The families of the Generalized Linear model adopted because of the nature of the study data are Normal (Linear Regression model), Gamma regression model and Inverse Gaussian regression model. The result showed that the Gamma and Inverse regression model best fitted the data set with each coefficient significant $(\mathrm{p}<0.05)$. The coefficients are interpreted thus using Gamma regression model:

The value of the coefficient of Quay Length (QL) equals 18119.141 which imply that an increase in QL will lead to increase in Gross Registered Tonnage Ocean Going (GOG) by about 18119 when other input variables are held constant.

The value of the coefficient of Berths equals -205224.740 which implies an increase in the number of Berths by one will lead to a decrease in Gross Registered Tonnage Ocean Going (GOG) by about 205224 when other input variables remain unchanged.

The value of the coefficient of Total Port Area (TPA) equals -15.702, indicates that when every other input variables in the model are held constant, that an increase in TPA by one unit will lead to a decrease in Gross Registered Tonnage Ocean Going (GOG) by about 15.

The value of the coefficient of Access Channel Depth(ACD) equals -1692182.290 indicate that when every other input variables in the model are held constant, an increase in ACD by one unit will lead to a decrease in Gross Registered Tonnage Ocean Going(GOG) by about 1692182.

Table 6 is the multivariate analysis of the relationship between the input variables and output variables. The result is unlike the univariate test in tables $5 \mathrm{i}$ to $5 \mathrm{iii}$ above. Multivariate analysis is when the effect of the input variables is measured on all the output variables simultaneously. The test statistics for the multivariate relationship measure are as listed in Table 6 above.

From the result of the analysis, it could be seen that the coefficient of QL, TPA and ACD are significant $(\mathrm{p}<0.05)$ while Berths are not. This suggests that when all the output variables are considered simultaneously with all the input variables, under consideration there is a significant relationship on them except the Berths. 


\section{Conclusion}

This study has assessed the performance of six Nigeria's seaports using four input variables namely Quay Length (QL), Number of Berths (Berths), Total Port Area (TPA),Access Channel Depth (ACD), and three output variables namely Cargo Throughput (CTP), Ship Traffic (ST), and Gross Registered Tonnage Ocean Going (GOG). The Open Access Rstatistical Software Version 3.4was employed to solve the relative efficiencies and benchmarking of the 6 Nigeria's seaports. The SPSS version 20 was also employed to analyze the significance and effect of the input variables and the output variables simultaneously. In answering the following research questions;

How significant is the relationship between the input and output variables used in this study?

Based on the result of the regression models in tables $5 \mathrm{i}$ to 5 iii and multivariate analysis in table 6 , the input variables has a significant relationship with output variables.

How has the seaports performed in Nigeria over the study period?

Based on the result of the DEA in tables 3 and 4, using constant return to scale, the following Seaports performed most efficiently: Lagos Port (LP) in 2014, Tin Can Island Port (TCP) in 2014, Onne Port (OP) in 2014, and Calabar Port (CP) from 2012 to 2014 and 2016. The least performed seaport is Delta Port (DP) in 2012. It is clear that the most efficient port over the year under study is Calabar Port (CP) while least performed port is Delta Port (DP).

How best can the individual seaports operate optimally based on their respective input mix?

The individual port can operate optimally by putting into consideration the values of the input and output slacks on table 3 and 4.

Which seaport could serve as a benchmark to other ports in Nigeria?

Calabar Port (CP) port can serve as Benchmark seaport within the year under review because Calabar Port (CP) from 2012 to 2014 and 2016 showed the highest number of efficiencies.

\section{Test of Hypothesis}

Ho: There is no significant relationship between the input variables and the output variables.

Based on the result of the regression model as well as the multivariate analysis in tables $5 \mathrm{i}$, to 6 , we reject the null hypothesis and state that at $5 \%$ level of significance that there is a significant $(\mathrm{p}<0.05)$ relationship between the input variables and output variables.

\section{Recommendations}

The study has shown that the performance of Calabar port is most efficient than other ports. This could be as a result of the ease of cargo movement into and out of the port. For Calabar seaport to be this efficient, the hinterland road networks are devoid of chronic vehicular congestions which would have hindered the smooth evacuation of goods in and out of the state. Though, Calabar seaport has smaller size of input variables when compared to some other ports in this study which could be the reason for its efficiency, therefore more cargo should be routed to other ports to enhance their optimality also.

The Nigeria's seaports enjoyed a boom in 2014 as shown in the study, which could connote that the volume of trade between Nigeria and other counties was high. This also means that there was growth in the revenue base of Nigerian Ports Authority and by extension the Nigeria economy.

The statistical prove of the significance and importance of quay length variable in seaports over other input variables such as (Number of Berths, Access Channel Depth, Total Port Area) as applied in this study, have also shown that in the course of prioritizing investment in the ports, the quay length should be considered as paramount in the development of any new port and expansion of old ports because of its positive impacts on the output variables (Ship Traffic, Cargo Throughput, and Gross Registered Tonnage Ocean Going) as used in this study. Though further empirical tests in this research shows that Quay length, Total Port Area, and Access Channel Depth have effect on the output variable while number of berths has little or no effect statistically. 


\section{Compliance with ethical standards}

\section{Acknowledgments}

The Authors are grateful to everyone whose advice was helpful to this study. We thank NPA for making materials available through their annual publications in magazines and journals. We are grateful to many Authors whose articles provided good references to this study. Lastly, we are indebted to the Editor who found this manuscript of good quality to be published in your reputable journal.

\section{Disclosure of conflict of interest}

There is no conflict of interest.

\section{References}

[1] A. S. Ogunsiji \& O. O. Ogunsiji. Comparative Ports Performance Efficiency Measurement in Developing Nations: A Matching Framework Analysis (M FA). Approach European Journal of Social Sciences - 2011; Volume 18, Number 4:625.

[2] Banker , R.D., Charnes, A and Cooper, W.W. Data Envelopment Analysis: Theory and Applications Proceedings of the 10th International Conference on DEA, Natal, Brazil Fox School of Business and Management, Temple University Philadelphia, PA 19121 USA. 2012

[3] Banker, R.D., Charnes, A, and Cooper, W.W. Some models for estimating technical and scale inefficiencies in data envelopment analysis, Management Science, 1984; 30(9):p. 1078-1092.

[4] Charnes, A., Cooper, W.W and Rhodes, E. measuring the efficiency of DMUs, European Journal of Operational Research, 1978; 2:p. 429-444.

[5] Cooper, W.W., Seiford, L.M and Tone, K. Data Envelopment Analysis: A comprehensive Text with Models, Applications, References and DEA-Solver Software, Kluwer Academic Publishers. 2004

[6] Cooper, D.R., and Schindler P.S. Business Research Methods International Edition McGraw Hill, 8th Edition. 2003

[7] Evangelos L. Kaisar, SomchaiPathomsiri, Ali Haghani Efficiency Measurement of US Ports Using Data Envelopment Analysis. National Urban Freight Conference, February2006; 1-3,

[8] Evangelos L. Kaisar, Somchai Pathomsiri, Ali Haghani, and Pantelis Kourkounakis Developing Measures of US Ports Productivity and Performance: Using DEA and FDH Approaches. Transportation Research Forum, 2006 March; 23-25,

[9] Emeghara and Ndikom Delay Factors Evaluation of Nigerian Seaports (A Case Study of Apapa Ports Complex, Lagos), Nigeria. Greener journal of physical sciences2012

[10] Nwanosike, Felicia O., Nicoleta S. Tipi and David Warnock-Smith Productivity Change in Nigerian Seaports after Reform: A Malmquist Productivity Index Decomposition Approach. The Flagship Journal of International Shipping and Port Research2016; Volume 43,

[11] Hlali Arbia 2018Efficiency Analysis with Different Models: The Case of Container Ports. J Marine Sci Res Dev 8: 250. Doi: 10.4172/2155-9910.1000250 Page 2 of 10 J Marine Sci Res Dev, an Open Access Journal Volume 8 • Issue 2 • 1000250 ISSN: 2155-9910

[12] Hong-Oanh Nguyen, Hong-Van Nguyen, Young-Tae Chang, Anthony T. H. Chin and Jose Tongzon Measuring port efficiency using bootstrapped DEA: the case of Vietnamese ports Maritime policy and management Volume 43, 2016; Issue 5:Pages 644-659

[13] Jara-Diaz S. Martines-Budria, E. Cortes, C. and Basso, L. A Multi output Cost Function for the Services of Spanish Ports Infrastructure, Transportation2002; 29:pp. 419-437.

[14] Karen Vassoler Martins, Marta Monteiro Da Costa Cruz The Investment in Ports Enterprises in Espirito Santo, Brazil .Proceedings of The 10th International Conference On DEA - Brazil2012

[15] Medal-Bartual, M. Molinos-Senante and R. Sala-Garrido Productivity change of the Spanish Port System: impact of the economic crisis Maritime policy and management2016; Volume 43, Issue 6Pages 683-705

[16] NPA Handbook 2018/2019 
[17] Onwuegbuchunam Donatus E. Productivity and Efficiency of Nigeria's seaports: A Production Frontier Analysis. International Business Management 2012; 6(1):41-46.Medwell Journals

[18] Okeudo, G. N. Measurement of Efficiency Level in Nigerian Seaport after Reform Policy Implementation. Case study of Onne and Rivers Seaport Nigeria. IOSR Journal of Business and Management (IOSR-JBM) E-ISSN: 2278487X, P-ISSN: 2319-7668.2013; Volume 12, Issue 5 (Jul. - Aug. 2013): PP 46-55 www.Iosrjournals.

[19] Peter Wanke, Obioma R. Nwaogbe and Zhongfei Chen Efficiency in Nigerian ports: handling imprecise data with a two-stage fuzzy approach Maritime Policy and management.2017; Volume 45, 2018 - Issue 5:Pages 699-715

[20] Ro -Kyung, P. and Prabir De "An Alternative Approach to Efficiency Measurement of Seaport." Maritime Economics and Logistics,2004; 6:53-69

[21] SoonHoo So, JaeJon Kim, Geon Cho and Do-Kwan Kim Efficiency Analysis and Ranking of Major Container Ports in Northeast Asia: An Application of Data Envelopment Analysis International Review of Business Research Papers2007;Vol.3 No.2 June: Pp. 486 - 503486

[22] Talley, W. K. Optimum Throughput and Performance Evaluation of Marine Terminals, Maritime Policy and Management,1998; Vol. 15, No. 4:pp. 327-331.

[23] Tongzon J Efficiency Measurement Of Selected Australian And Other International Ports Using Data Envelopment Analysis, Transportation Research Part A Policy and Practice2001;35(2):113 - 128.

[24] Turner, H. Windle, R. and Dresner, M. North American Container port: 1984 -1997, Transportation Research Part 2004; E, 40:pp. 339 - 356.

[25] Madueke Ugonna. A. 2013Measuring and Benchmarking Efficiency and Productivity Levels of Liquid Bulk Terminal Operations Using a DEA AND OEE Approach Considering Nigeria's Atlas Cove Jetty and Depot Facility (M.Sc. Thesis) in Maritime Economics and Logistics. Erasmus University Rotterdam

[26] Umang, et al 2011 The Berth Allocation Problem in Bulk Ports

[27] UNCTAD 2009 Review of Maritime Transport New York and Geneva. 